\title{
BIBECHANA
}

A Multidisciplinary Journal of Science, Technology and Mathematics

ISSN 2091-0762 (online)

Journal homepage: http://nepjol.info/index.php/BIBECHANA

\section{Anthropogenic impact on wetland bird diversity in and around of Budhi and Tengra rivers of Itahari Municipality}

\author{
Sanju Dahal, Damodar Thapa Chhetry* \\ Department of Zoology, Post Graduate Campus, T.U. Biratnagar, Nepal \\ Corresponding Author Email: thp damodar@rediffmail.com \\ Article history: Received 25 September, 2012; Accepted 15 November, 2012
}

\begin{abstract}
The diversity and population of birds was studied from January, 2011 to December, 2011, once a week regularly. Altogether fifteen species of wetland birds were recorded from Tengra and Budhi rivers. Maximum species were recorded in January and minimum in July and August. Out of total bird species $40 \%$ were migratory, $46.67 \%$ were resident, and $13.33 \%$ were winter visitors. On the basis of abundance, there were $46.67 \%$ scarce, $33.33 \%$ fairly common and $20 \%$ common. On the basis of their population status, maximum number belonged to Ardeola grayii species and minimum in Leptoptilos javanicus species. Maximum species of the birds belonged to family Ardeidae. According to statistical analysis, the resident bird were more diversed then migrant and winter visitor respectively. Similarly, resident birds were much evenly distributed then winter visitors and migrant respectively. The study revealed decreasing trend of bird species from previous period. The conversion of wetland into agricultural land and plotting programmes were the main causes to decline the bird species.
\end{abstract}

Keywords: Budhi and Tengra River; Bird diversity; Anthropogenic impact.

\section{Introduction}

Birds are the beautiful creatures of nature. Nepal is rich in bird diversity. There are 865 species of birds in Nepal [1]. According to IUCN category [2] list, 27 birds species are as threatened, 31 as critical, 44 as endangered, 54 as vulnerable, 1 having insufficient data and 9 as species needing more ecological information [3].

But the bird diversity threats are increased by human interference, direct and indirect resulting in habitat destruction and fragmentation. Anthropogenic activities like mass bathing in holy ponds, cutting of emergent and fringed vegetation, draining of water, release of sewage, throwing of domestic garbage, weeds, developmental activities like construction of roads and retaining walls are some major threats to the birds. Nepal's wetlands face threats from drainage, diversion, siltation, over enrichment, pollution and poisons used to kill the fish. 
The mounting pressure of population explosion in the world including Nepal indicates increasing food shortage. So, anthropogenic impact being a burning issue which is extending day by day.

\section{Study Area}

In and around of Budhi and Tengra Rivers of Itahari, Municipality, Sunsari (fig. 1) were chosen for the study of wetland birds.

\section{Budhi River}

Budhi river is one of the most important river of Sunsari district which is originated from foot hill of Mahabharat range. It flows eastern boarder of Sunsari district and separates Sunsari district from Morang district. It passes through Dharan-Biratnagar highway at Duhabi. This river flows with a definite course from its origin from Nepal to India boarder. This river passes through Charkoshe Jhadee situated east of Dharan-Biratnagar highway. In this river, water remains throughout the year. Sunsari-Morang Irrigational Canal crosses this river near Sisbani Badahara Village of Morang, and number of outlet of this canal finally meets Budhi river and it also acts as a escape drainage for Sunsari-Morang irrigation project. At the rainy season, the water of Sunsari Morang Irrigation Canal contains maximum amount of silt and clay which enters into the river through different outlet so that the water of this river becomes highly silty and turbid.

The water of Budhi river is clear in dry season. The sediment load in this season is zero. The sediment load is highest during the rainy season. In this season, the strong current also causes soil erosion and silting.

The water level during the winter and summer decreases to considerable amount but doesn't dry up. Hence, the rivers is potentially important for aquatic life as well as for the irrigation.

\section{Tengra River}

Tengra river is one of the most important river of Sunsari district. It originates from the north of Pindeswor and flows eastern side of Sunsari district. It passes through Dharan-Biratnagar highway at south of Itahari. This river also passes through Charkoshe Jhadee situated south of Dharan upto Tarahara. In this river water generally remains throughout the year. Sunsari-Morang Irrigation canal crosses the river at Khanar village. And number of outlet of this canal finally meets the Tengra river and it also acts as a escape drainage for Sunsari-Morang Irrigation Project. At the rainy season the water of Sunsari Morang Irrigation canal contains maximum amount of silt and clay which enters into the river through different outlet of this canal. So, that the water of this river becomes highly silty and turbid. This river finally meets with Budhi river at south-east of Sonapur. 


\section{Materials and Methods}

The diversity and population of birds was studied from January, 2011 to December, 2011, once a week regularly. Birds were counted by the direct observation and also collected informations from the local people. For the study of birds, Binoculars (Tasco, 8x21 magnification), Camera (Cannon 10 megapixel),

Field dairy were used. Similarly, for the identification of the bird species, the main field books of Fleming et.al.[4], Inskipp and Inskipp [5], Shrestha [3], (Grimmett et al.[1], were used. The list of observed bird was prepared.

For the statistical analysis, species diversity of birds and evenness of species were calculated by using following methods:

a. Shannon - Weaver diversity Index $(\overline{\mathrm{H}})=-\Sigma$ Pi log2 Pi [6]

where, $\mathrm{Pi}=$ Proportion of individuals

b. Evenness Index $(e)=\overline{\bar{H}}_{\max }[7]$

$$
\overline{\mathrm{H}}_{\max }=\log _{2} \mathrm{~s}
$$

where $\mathrm{s}=$ number of species.

Anthropogenic impacts were studied through direct field visit and informations were collected by informal interview with local people.

\section{Results}

Altogether fifteen species of wetland birds were recorded from Tengra and Budhi rivers. Thirteen species were recorded in January and only four in July and August. Total numbers of individuals counted during study period were 350 .

On the basis of their population status, maximum (sixty five) belonged to Ardeola grayii species and the least, (two) belonged to Leptoptilos javanicus species. On the basis of abundance, $46.67 \%$ birds were scarce, $33.33 \%$ were fairly common and $20 \%$ were common birds in study area. Maximum species of the birds belonged to family Ardeidae (Table 1). Variation of bird species and total number of individuals of the bird species on monthly basis have been shown in fig. 2 and fig. 3 respectively. Seasonal status and abundance of birds on percentage basis have been shown in fig. 4 and fig. 5 respectively. 


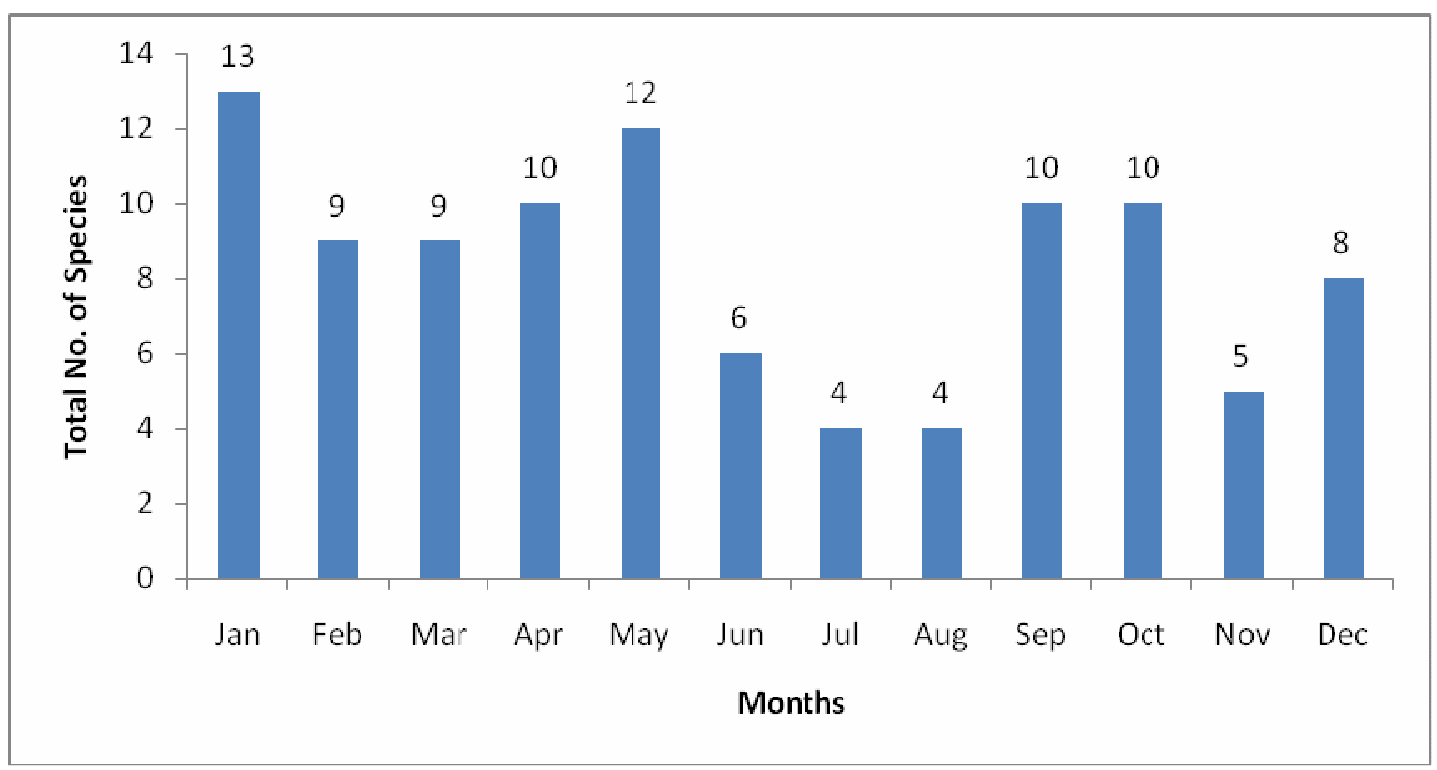

Fig. 2: Variation of the bird species on monthly basis

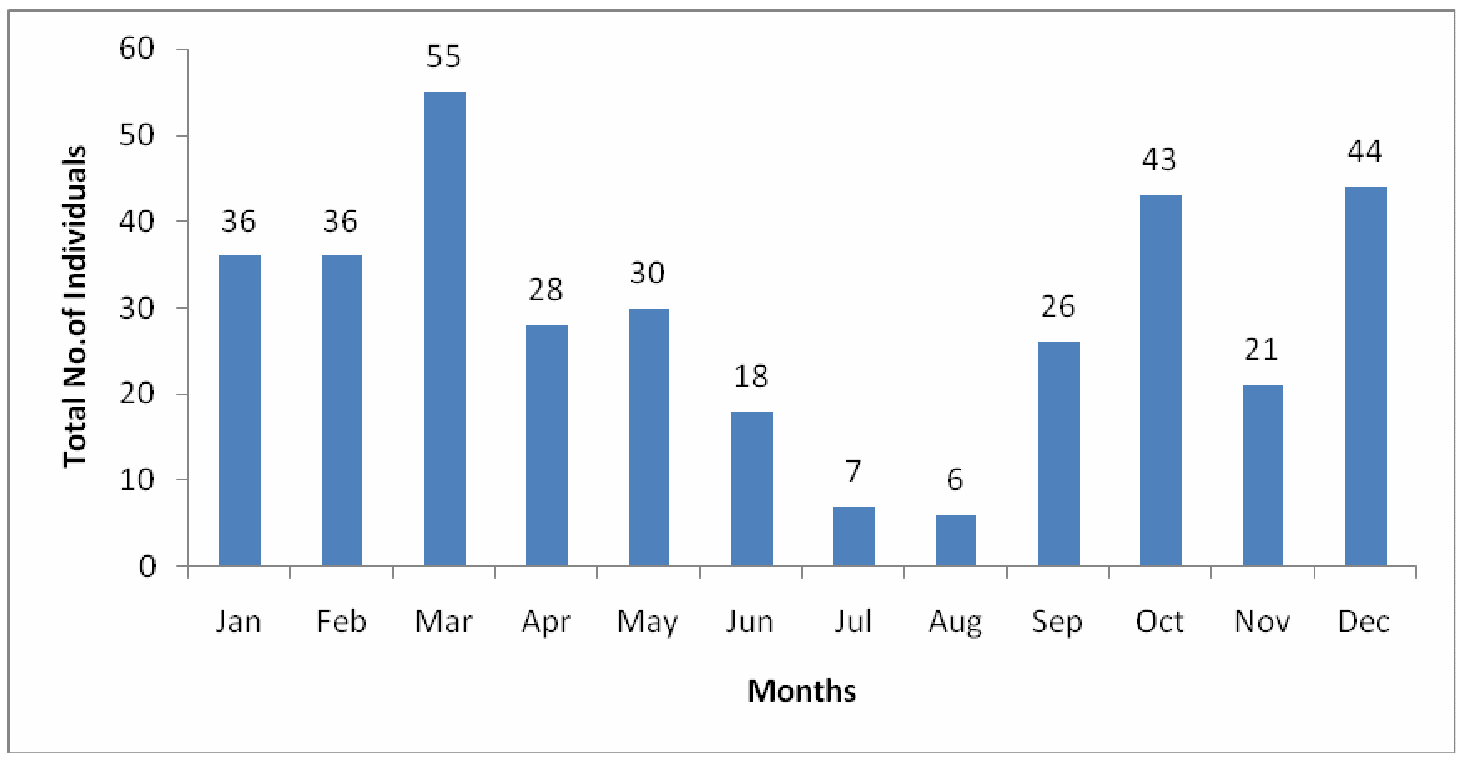

Fig. 3: Variation of total no. of individuals on monthly basis 
Pie- diagrams

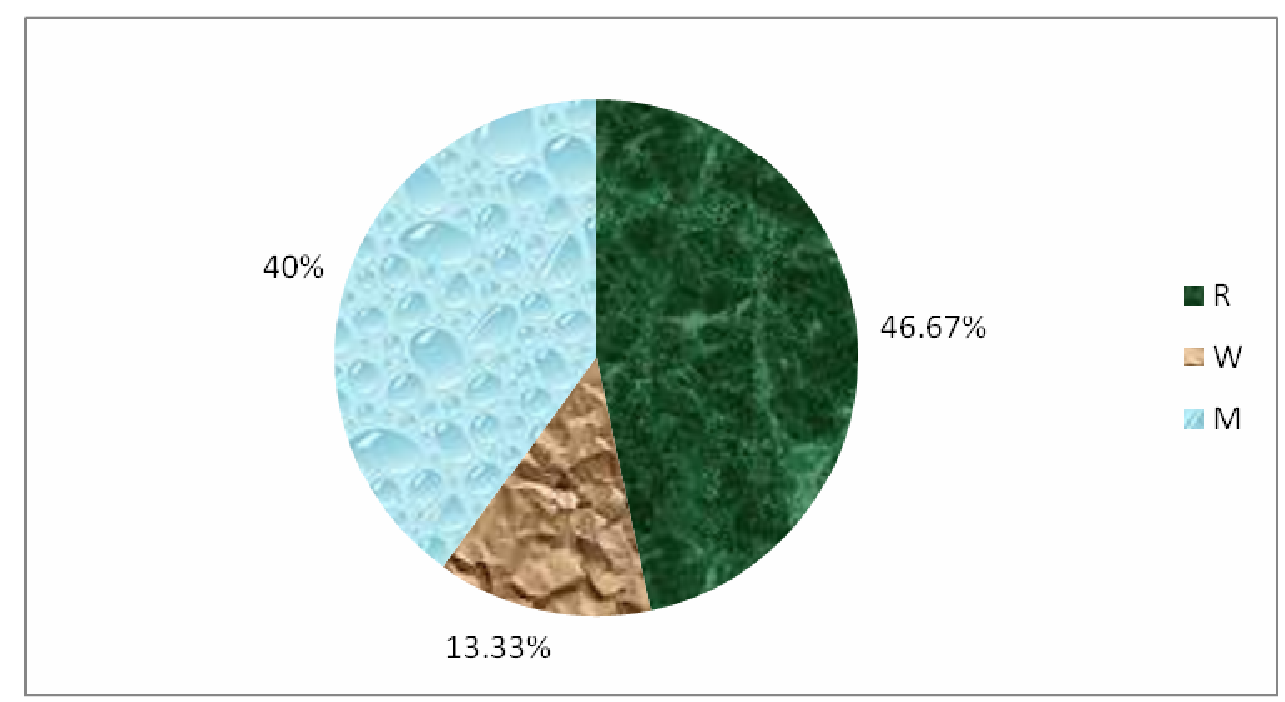

Fig. 4: Seasonal Status of birds on percentage basis

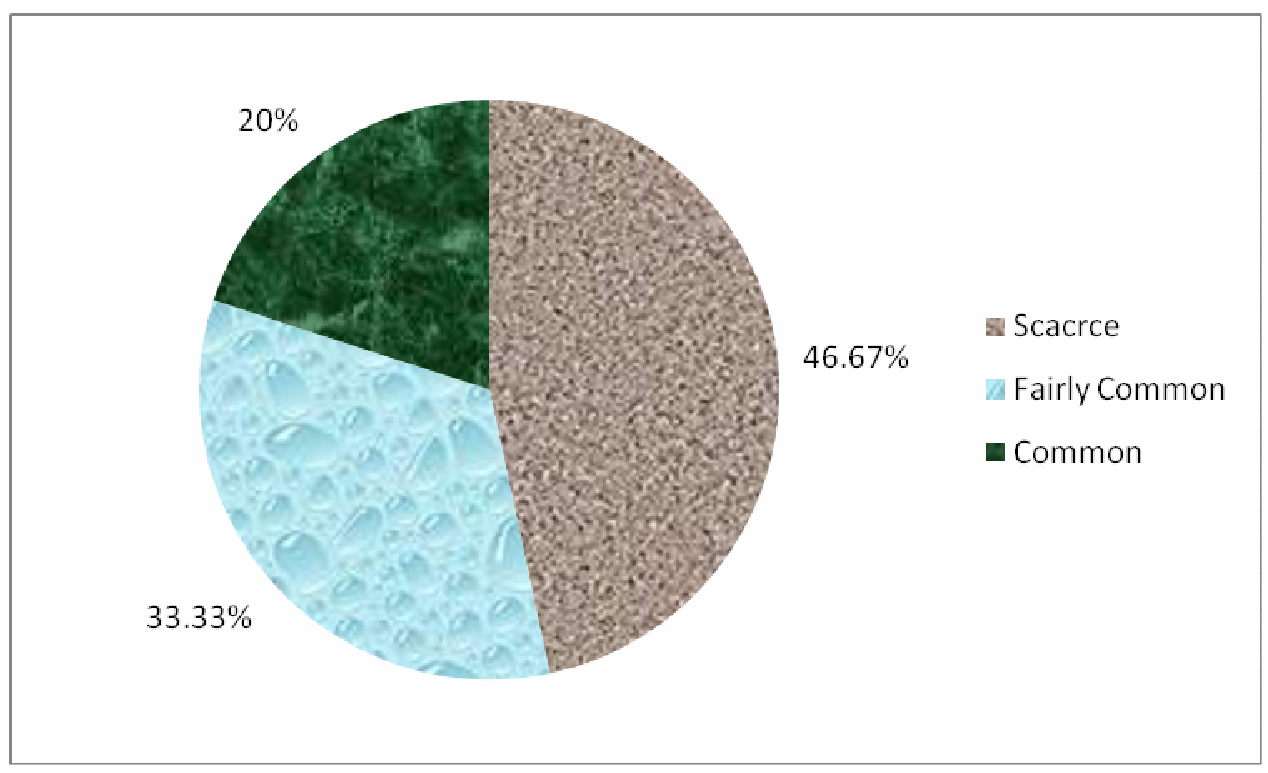

Fig. 5: Abundance of birds on percentage basis 
According to statistical analysis, the resident birds were more diversed then migrant and winter visitor birds respectively (Table 2, 3 and 4). Similarly, resident birds were much evenly distributed then winter visitors and migrant birds respectively (Table 5 ).

Table 2: Analysis of Species Diversity of Resident Birds

\begin{tabular}{|l|l|l|l|l|l|l|}
\hline S.N. & Name of Species & $\mathrm{n}$ & $\mathrm{P}_{\mathrm{i}}$ & $\log \mathrm{P}_{\mathrm{i}}$ & $\log _{2} \mathrm{P}_{\mathrm{i}}$ & $\mathrm{P}_{\mathrm{i}} \log _{2} \mathrm{P}_{\mathrm{i}}$ \\
\hline 1 & Ardeola grayii & 65 & 0.2416 & -0.6169 & -2.0493 & -0.4951 \\
\hline 2 & Bubulcus ibis & 63 & 0.2342 & -0.6304 & -2.0941 & -0.4904 \\
\hline 3 & Egretta garzetta & 29 & 0.1078 & -0.9673 & -3.2133 & -0.3464 \\
\hline 4 & Egretta intermedia & 40 & 0.1487 & -0.8277 & -2.7495 & -0.4088 \\
\hline 5 & Anastomus oscitans & 37 & 0.1375 & -0.8617 & -2.8625 & -0.3966 \\
\hline 6 & Pseudibis papillosa & 26 & 0.0966 & -1.0150 & -3.3717 & -0.3257 \\
\hline 7 & Ceryle rudis & 9 & 0.0334 & -1.4762 & -4.9038 & -0.1638 \\
\hline & Total & 269 & & & & -2.6238 \\
\hline
\end{tabular}

Table 3: Analysis of species Diversity of Migrant Birds

\begin{tabular}{|l|l|l|l|l|l|l|}
\hline S.N. & Name of Species & $\mathrm{n}$ & $\mathrm{P}_{\mathrm{i}}$ & $\log _{\mathrm{i}}$ & $\log _{2} \mathrm{P}_{\mathrm{i}}$ & $\mathrm{P}_{\mathrm{i}} \log _{2} \mathrm{P}_{\mathrm{i}}$ \\
\hline 1 & Nycticorax nycticorax & 9 & 0.2368 & -0.6256 & -2.0782 & -0.4921 \\
\hline 2 & Leptoptilos javanicus & 2 & 0.0526 & -1.2790 & -4.2487 & -0.2235 \\
\hline 3 & Halcyon smyrnensis & 5 & 0.0131 & -1.8827 & -6.2541 & -0.0819 \\
\hline 4 & Alcedo atthis & 4 & 0.0153 & -1.8153 & -6.0302 & -0.0923 \\
\hline 5 & Alcedo meninting & 3 & 0.0789 & -1.1029 & -3.6637 & -0.2890 \\
\hline 6 & Vanellus indicus & 15 & 0.0395 & -1.4034 & -4.6619 & 0.1841 \\
\hline & Total & $\mathbf{3 8}$ & & & & $\mathbf{- 1 . 3 6 2 9}$ \\
\hline
\end{tabular}

Table 4: Analysis of Species Diversity of winter visitor birds

\begin{tabular}{|l|l|l|l|l|l|l|}
\hline S.N. & Name of Species & $\mathrm{n}$ & $\mathrm{P}_{\mathrm{i}}$ & $\log \mathrm{P}_{\mathrm{i}}$ & $\log _{2} \mathrm{P}_{\mathrm{i}}$ & $\mathrm{P}_{\mathrm{i}} \log _{2} \mathrm{P}_{\mathrm{i}}$ \\
\hline 1 & Podiceps ruficollis & 9 & 0.2093 & -0.6792 & -2.2562 & -0.4722 \\
\hline 2 & Phalacrocorax niger & 34 & 0.7907 & -0.1019 & -0.3388 & -0.2679 \\
\hline & Total & 43 & & & & -0.7401 \\
\hline
\end{tabular}

\section{Discussion}

Birds are suffering at the hands of human in different ways. They hunt them, take their eggs and graze domestic animals or introduce exotic predators into their habitats. Habitat alteration, destruction or loss are the major threats to survival of birds [8]. In Koshi Tappu Wildlife Reserve, 461 species of birds representing 58 families were recorded. At least 176 species breed in the reserve and 180 species are passage migrant or visitors [9]

In the present study fifteen species of water birds belonging to seven families were recorded. Maximum number of species recorded during the study period of twelve months was thirteen in the month of January. Least number of birds, four species was recorded on July and August. This may be due to local migration of resident bird, departure of winter visitors and commencement of monsoon season and this may also be caused due to habitat destruction of birds.

The number of wetlands birds species recorded during this study period was compared with earlier records given by different researchers of various places. Subba [10] recorded 86 birds in Biratnagar. Pandey [11] recorded 104 species of birds in Itahari, out of which 22 were wetland birds. Surana [12] 
recorded 109 species of bird from Chimdi Lake of Sunsari district, out of which fifty four species were wetland birds. Similarly, Thapa Chhetry [13] reported hundred species of wetland birds from the wetlands of Koshi Tappu Wildlife Reserve and its surroundings. Comparatively, the present study recorded less number of bird species.

The present study showed decreasing trend of bird species from previous record, this may be due to different kinds of human activities. The feeding habit of bird has been highly affected by the urbanization and industrialization of the city. Human beings are playing a destructive role to unbalance the system of nature. The main anthropogenic impacts were observed to decline the wetland birds are conversion of most of the wetlands around Taltalaiya area of Itahari into agricultural land, urbanization, pesticides, increment of human population by immigration from hills and mountains, cultivable lands have been changed into plotted area for construction and lands are left unfarmed etc.

\section{Conclusions}

The declining of bird species is mainly due to the anthropogenic factors. The anthropogenic factors include establishment of industry, urbanization, agriculture, mining, transportation, construction, waste disposal practices, vehicular air pollution, concentration of sewage and debris, habitat loss, encroachment on wetlands, loss of feeding ground, use of insecticide, lack of awareness about importance of birds.

So, the study can be concluded that for the restoration of wetland bird species proper management, conservation planning and infrastructure development are essential.

\section{References}

[1] R. Grimmett, C. Inskipp, T. Inskipp, Birds of Nepal, Christopher Helm. London (2009).

[2] IUCN, An Inventory of Nepal's Wetlands, IUCN-Nepal Kathmandu (1996).

[3] T.K. Shrestha, Birds of Nepal, Field Ecology, Natural HIstory and Conservation, Vol. I. R.K. Printers. Kathmandu (2000).

[4] Sr. R.L. Fleming, Jr. R.J. Fleming, and L.S. Bangdel Birds of Nepal. Second Edition, Avalok, Kathmandu (1979).

[5] C. Inskipp, and J. Inskipp A Guide to the Birds of Nepal, Christopher Helm. London (1985).

[6] C.E. Shannon and W. Weaver The mathmatical theory of communication, University of Illinois press, urbana (1963).

[7] E.C. Pielou The measurement of Diversity in different types of biological Collection, J. Theoret Diol, 1-3 (1966) 131-144.

[8] H.S. Baral,, C. Inskipp, T. Inskipp and U.R. Regmi Threatened Birds of Nepal, Bird Conservation Nepal and Department of National Park and Wild Life Conservation, Kathmandu (1996).

[9] IUCN An Interpretation and Education system for Koshi Tappu Wildlife Reserve and its Buffer zones, IUCN Nepal (1998).

[10] Subba, B.R. Checklist of Birds of Biratnagar, Newsletter for Bird Watchers, 34 (6) (1994) 128 - 129

[11] M.R. Pandey Birds of Itahari, J. Our Nature, Nature Conservation and Health Care Council, Biratnagar, Nepal, 1 (1) (2003) 64 - 67.

[12] R. Surana, Wetland Ecology of Chimdi Lake (Birju Tal), Sunsari District, Eastern Nepal, Department of Zoology, Post-Graduate Campus, Biratnagar, Tribhuwan University (M.Sc. Dissertation) (2005).

[13] D. Thapa Chhetry Studies on physico-chemical parameters and macrobiota with special reference to fishes in the wetland of Koshi Tappu Wildlife Reserve and its surroundings, Nepal, Ph. D. Thesis, North Bengal University, India (2006). 